DEAF IN THE USSR 



\section{DEAF IN THE USSR}

MARGINALITY, COMMUNITY, AND SOVIET IDENTITY, 1917-1991

Claire L. Shaw 
Publication of this book was made possible, in part, by a grant from the First Book Subvention Program of the Association for Slavic, East European, and Eurasian Studies.

Copyright (C) 2017 by Cornell University

All rights reserved. Except for brief quotations in a review, this book, or parts thereof, must not be reproduced in any form without permission in writing from the publisher. For information, address Cornell University Press, Sage House, 512 East State Street, Ithaca, New York 14850.

First published 2017 by Cornell University Press

Printed in the United States of America

Library of Congress Cataloging-in-Publication Data

Names: Shaw, Claire L., author.

Title: Deaf in the USSR : marginality, community, and Soviet identity, 1917-1991 / Claire L. Shaw.

Description: Ithaca : Cornell University Press, 2017. Includes bibliographical references and index.

Identifiers: LCCN 2017006013 (print) | LCCN 2017008102 (ebook) | ISBN 9781501713668 (cloth : alk. paper) | ISBN 9781501713781 (epub/mobi) | ISBN 9781501713798 (pdf)

Subjects: LCSH: Deaf culture-Soviet Union—History. | Deaf-Soviet Union-Social conditions. | Marginality, Social—Soviet Union—History. | Identity (Psychology)— Soviet Union—History. | Group identity—Soviet Union-History.

Classification: LCC HV2783 S44 2017 (print) | LCC HV2783 (ebook) | DDC 305.9/08209470904-dc23

LC record available at https://1ccn.loc.gov/2017006013

Cornell University Press strives to use environmentally responsible suppliers and materials to the fullest extent possible in the publishing of its books. Such materials include vegetable-based, low-VOC inks and acid-free papers that are recycled, totally chlorine-free, or partly composed of nonwood fibers. For further information, visit our website at www.cornellpress.cornell.edu.

Cover: Deaf workers from the "Paris Commune" factory meet the Stakhanovite Smetanin, 1935. Reproduced with the permission of the Central Museum of the History of VOG. 
For Ruth, Tony, and Edward 
We do our deeds in silence,

And our deeds speak for us.

—Deaf Soviet poet Ivan Isaev, 1971 